\title{
Distribution of Benthic Macroinvertebrates in Seafloor Northward of Pulau Indah, Klang
}

\author{
Mohd Sophian Mohd Kasihmuddin* and Zaidi Che Cob \\ Department of Earth Sciences and Environment, Universiti Kebangsaan Malaysia, \\ 43600 UKM, Bangi, Selangor, Malaysia
}

\begin{abstract}
An assessment of community of benthic macroinvertebrates in waters northwards of Pulau Indah, Klang was made with the main objective to determine distribution and diversity of benthic macroinvertebrates as well as to establish possible correlation between the community's distributions with environmental parameters. The sediments were obtained via Ponar Grab $\left(0.023 \mathrm{~m}^{2}\right.$ mouth area), followed by filtration $(500 \mu \mathrm{m})$ and laboratory sorting in order to extract all specimens from sediments. The specimens were identified to the lowest taxonomic hierachy as possible. The physical parameters such as organic carbon (TOC) and grain size distributions were analysed. A total of 775 annelids, 15 arthropods, 12 echinoderms and 32 molluscs individuals were identified and recorded in six stations overall. Family Cirratulidae accounted to the highest numbers of the Annelids $(n=358)$, whilst Cerithidae recorded as highest numbers of Molluscs. Station 5, 6 and 1 recorded

ARTICLE INFO

Article history:

Received: 13 August 3030

Accepted: 5 November 2020

Published: 22 January 2021

DOI: https://doi.org/10.47836/pjst.29.1.34

E-mail addresses:

sophianmkmaidin@gmail.com (Mohd Sophian Mohd

Kasihmuddin)

zdcc@ukm.edu.my (Zaidi Che Cob)

*Corresponding author

the highest diversity index $\left(H^{\prime}=2.1845\right)$, evenness index $\left(J^{\prime}=0.6316\right)$ and richness index $\left(D_{m n}=22.0454\right)$ respectively. Principal Component Analysis indicated sediment particle size as the major connector on all stations, with different station correlated to certain sizes of sediment particle. Pearson correlation analysis showed positive correlations between environmental parameters with eight benthic taxa in this study, with most correlations were on
\end{abstract}


specific sediment particle size. As the study of benthic community is still inadequate in most of Malaysians waters, particularly in highly industrialised area such as waters in Port Klang, this study can serve as a starting point for any future studies concerning ecological disturbance affecting benthic community in Malaysian waters.

Keywords: Gastropod, Macrobenthos, Polychaete, Port Klang, Pulau Indah, Zooplankton

\section{INTRODUCTION}

Benthic macroinvertebrates are ubiquitous in seafloors all over the world. Their simple but unique lifeform enables them to adapt and survive in various conditions at the seafloor. They are regarded as ecosystem engineers, where they help ensuring the sediment environment habitable for other groups of marine organisms to thrive (Lu, 2005; Queirós et al., 2013).

Generally, benthic macroinvertebrates are found to be highly concentrated at softbottom sediment closer to the shore (Hossain, 2018) and also found along the continental shelves, where the region is still considered as euphotic zone and rich in nutrients (Vijapure et al., 2018). Peninsular Malaysia is well known to have shallower continental shelves and lesser water depth around it, especially at Straits of Malacca and Johor (Nakajima et al., 2009). These features grant numerous benefits to benthic community such as better foraging grounds and better establishment of guilds. Study in Sungai Pulai by Guan et al. (2014) estuary also shows variations in terms of spatial factor, where crustaceans and polychaetes were found to be highly concentrated in Tanjung Adang (located closer to land) and Merambong Shoal (located far off land) respectively. Their study area is known to have less human intrusion and populated by seagrasses but vulnerable to anthropogenic activities. Study by Mohammad and Jalal (2018) indicated that faunal variation in zones off human settlements in Kuala Pahang along Pahang Estuary was higher than the zones nearby Kuala Pahang itself. Their study recorded higher volume of polychaetes, gastropods and bivalves off Kuala Pahang but records otherwise around Kuala Pahang. Study by Sany et al. (2014) around West Port, Klang recorded 23 Molluscs, 3 Echinoderms, 4 Arthropods and 3 Annelids taxa in 9 stations across the West Port waterways, with molluscs and arthropods dominating stations closer to Pulau Kelang, which is known to have higher volume of mangrove trees and lesser human intrusions. Based on these studies, it could be deduced that spatial variations of benthic macroinvertebrates were influenced by nearby vicinities these benthic communities are located on. The number of benthic macroinvertebrate studies in Malaysian waters especially in areas with heavy anthropogenic activities are still lacking, especially in areas like ports and berths (Sany et al., 2014). As most assessments on benthic community in Malaysian waters were done via cluster sampling but limited to only one point source, this study focused not only utilizing similar sampling method, but also on multiple point comprising mangrove forests in Pulau Kelang, Sungai Klang 
estuaries and waterways from Southpoint and North Port, and this study could serve as a useful reference when conducting cluster sampling in areas surrounded by various point sources such as mangrove estuaries (Al-Khayat et al., 2018; Taupp \& Wetzel, 2018), ports and berths (Belal et al., 2020) and waterways (Arbi et al., 2017).

Environmental parameters also influence dispersion and dominance of macrobenthos in soft-bottom sediment. Macrobenthos in estuaries are generally highly diverse due to constant influx of nutrients from nearby mangrove areas, but any disturbance to the mangrove areas can directly affect the community as a whole ( $\mathrm{Lu}, 2005)$. In Brazil, deforestation of mangrove forests effectively reduces the macrobenthos in the studied mudflat areas from 6000 individuals to less than 50 individuals (Bernadino et al., 2018). Deforestation that occurred in the study indicates alteration of the nature of sediment and lesser detritus which is necessary for macrobenthos to thrive. Mosbahi et al. (2019) showed higher diversity of macrobenthos off the coast of Sfax, Tunisia, attributed by lesser exposure to pollutants such as heavy metals further off the coast. Areas with higher heavy metal concentration consist of mostly opportunistic polychaetes such as Cirratulus cirratus and Capitella capitata whereas in areas with lesser heavy metal concentration consists of sensitive species such as Euclymene oerstedi and Cymadusa filose. These substrates may originate from the mainland or from certain point source such as fish farm and ports. Quimpo et al. (2020) related the impact of fish farm with lower rate of larval settlement for coral species, strongly implied influx of excess substrates such as unconsumed fish feed and fecal materials from the farm into the sediment. Consequently, this leads to introduction of uncontrollable dominance of algae, opportunistic polychaete and bacteria, in which makes the settlement of larval coral species difficult. In Malaysian waters, Zhen et al. (2020) focused on assessing macrobenthic community at three mudflat sites off Perak and Selangor. The study recorded Bagan Nakhoda Omar site as the highest taxa diversity due to higher chlorophyll- $a$, attributing to higher number of gastropods inhabiting the area, and another two sites, Bagan Sungai Buloh and Kuala Sangga Besar contained lower taxa diversity, attributed by higher ammonia level settling in sediment, possibly originating from nearby estuaries. Sany et al. (2015) made an ecological assessment to benthic macroinvertebrates in West Port, Port Klang. Their study shows contrasting diversity across the waterway of West Port, with lowest diversity but higher dominance of opportunistic gastropods and polychaetes at zones closer to berth lines, and higher diversity of ecologically-sensitive gastropods and echinoderms at southern end of West Port waterway, which has lesser human infrastructures in nearby.

Assessments made in this area (Port Klang) besides Sany et al. (2015) are still lacking overall if not, may not be contemporary with current state of pollution taking place around Port Klang in general. Data obtained from this study is may not tally with the current status of the benthic communities in this region. This study intends to establish connection of latest 
distribution of benthic community in the region and relate with the current environmental conditions. This study can help us in identifying possible ecological stresses in the region and suggesting appropriate benthic bioindicator species inhabiting it, in which their population may indicate the current status of ecosystem health of the habitat. The outcome of this study may put ways for other specialized studies on sediments at waters of Port Klang such as heavy metal (ELturk et al., 2019), oil spill (Omar et al., 2018) and bacterial activities in response to presence of certain benthic organisms inhabiting the sediment (Hanapiah et al., 2018).

Therefore, the objectives of this study were to (1) determine distributional pattern of benthic macroinvertebrates inhabiting soft-bottom sediments of study areas northwards of Pulau Indah, Klang and (2) to establish correlation between the distribution and diversity of benthic macroinvertebrates with the corresponding environmental parameters in the study.

\section{MATERIALS AND METHOD}

\section{Collection of Benthic Specimens and Sediment Samples}

Sampling was performed one-time in six selected points in waters northwards of Pulau Indah (Figure 1). Station 1 was located north of Pulau Indah, closer to mouth of Sungai Klang. Stations 2 and 3 were located at east side of Pulau Indah and with close proximity to the mainland Selangor. Finally, stations 4 to 6 were located at west side of the island, with the station 4 located between the water passage from Northpoint port northwards and Southpoint port eastwards. Stations 5 and 6 were situated closer to smaller estuaries in the pristine and uninhabited Pulau Mat Zin.

Triplicates of sediment samples were taken using a Ponar grab with $0.023 \mathrm{~m}^{2}$ mouth area for the purpose of assessing distribution of benthic macroinvertebrates, and another sediment sample was taken to assess the total organic carbon (TOC) and percentages of size particles of sediment (particle size distributon, PSD). Physical parameter such as salinity was taken using salinometer, while depth of water was taken using digital depth sounder. Sediments used for sorting specimens were filtered through $500 \mu \mathrm{m}$ sieve before being transferred into double plastic bag and preserved using $5 \%$ formalin in seawater.

\section{Sorting and Identification of Specimens and Analyses of Sediments}

Sediment samples were transferred into Borgorov Box, where specimens were sorted out using forceps under the view of dissecting microscope and transferred into vials containing $70 \%$ ethanol to further preserve the specimens. Digital photos of specimens were taken using microscope imaging software (DinoCapture 2.0). Specimens were identified into lowest taxonomic level as possible, using reference such as Fauchald and Jumars (1977), Idris and Arshad (2013), Nakajima et al. (2009), Ng and Davie (2002), Ng (2017), Fujita and Irimura (2015), Ong and Wong (2015), Baharuddin et al. (2018) and others. 


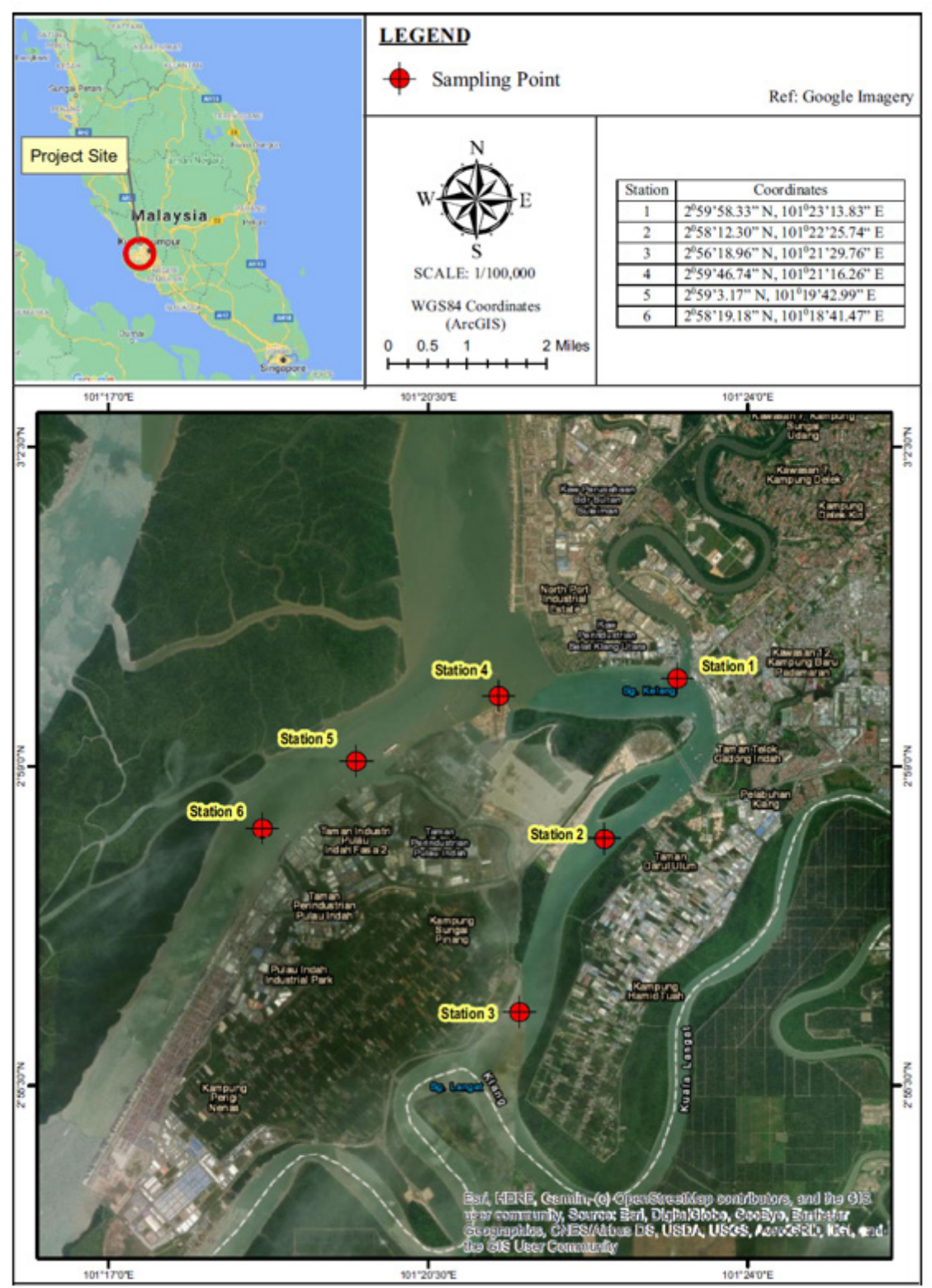

Figure 1. Location of all sampling points in this study

Sediments were stained with Rose Bengal solution, for easier identification under microscope due to pink coloration being applied onto specimens (Bernhard et al., 2006). Specimens were filtered immediately from sediments in the laboratory to reduce the abrasion effect by the sediment that could break specimens' body (Altuhafi \& Baudet 2011). 
Loss of Ignition (LOI) method was used to assess the total organic carbon in each sediment samples. Sediments were dried thoroughly in an oven for three days in $60^{\circ} \mathrm{C}$ before incineration in muffle furnace $\left(500^{\circ} \mathrm{C}\right)$ for four hours. The mass of sediment samples before and after burning were obtained and used to derive percentages of LOI and determine mass TOC in sediment in $\mathrm{g}$. In TOC analysis, the sediments must be oven-dried for three days straight to ensure sediment contain zero moisture; thereby reducing measurement error during weighing after muffle furnace phase (Equations [1] to [2]).

$$
\operatorname{LOI}(\%)=\frac{\left(W_{i}-W_{f}\right)}{W_{f}} \times 100 \%
$$

$$
\text { TOC }(g)=\text { LOI }(\%) \times 0.45
$$

A 0.45 coefficient was used as conversion factor for, based on standard carbon-nitrogen ratio in sediment (Huntington et al., 1988). For determination of percentage of particle size distribution, filtration method was used. Fifty (50) g of sediment samples were washed to remove impurities before passing through filtration set comprising a $2 \mathrm{~mm}$ sieve (for very fine sand), $1 \mathrm{~mm}$ sieve (for fine sand), $0.5 \mathrm{~mm}$ sieve (for medium-sized sand), 0.125 $\mathrm{mm}$ sieve (for coarse sand) and $0.063 \mathrm{~mm}$ sieve (for very coarse sand). The percentage of sediment samples were assessed by weighing the mass of sediment trapped in each level of the set.

\section{Data Analysis}

Ecological indices were calculated based on frequency distribution of macrobenthos organisms at each station. The Shannon-Wiener Diversity Index $\left(H^{\prime}\right)$, Pielou's Evenness Index $\left(J^{\prime}\right)$ and Menhinick Richness Index $\left(D_{m n}\right)$ were used to assess the state of ecosystem in each station. $H^{\prime}$ 'was used to assess diversity of taxa in one group, whereas $J$ ' assesses similarity of each taxon number in the group and $D_{m n}$ assess number of individuals of all taxa found in the group (Equations [3], [4], and [5]) (Mason et al., 2005).

$$
\begin{aligned}
& H^{\prime}=\sum_{i=1}^{\mathrm{S}} p_{i} \ln p_{i} \\
& J^{\prime}=\frac{H^{\prime}}{H_{\max }} \\
& D_{m n}=\frac{p_{i}}{\sqrt{N}}
\end{aligned}
$$

Where $p_{i}$ is individual number in one taxon, $H_{\max }$ is $\ln (\mathrm{s})$ of species diversity in the community under maximum equitability conditions, and $N$ is total number of individuals of 
all taxa in one group. For statistical analysis, data derived from environmental parameters and macrobenthos population parameters were subjected to one-way ANOVA test to determine data differences between stations, respectively. For correlation analysis, both data from environmental parameters and macrobenthos population parameters were used for Pearson correlation analysis. Principal Component Analysis was plotted to identify relationship between stations and environmental parameters recorded in this study. In this study, PAST 4.03 was used to assess one-way ANOVA test and PCA, and SPSS 1.0.0.1406 was used to assess Pearson Correlation Analysis.

\section{RESULT AND DISCUSSION}

\section{Distribution of Benthic Macroinvertebrates in Waters Surrounding Pulau Indah}

A total of 834 macrobenthos individuals comprising of 4 phyla were recorded in this study (Table 1). In order of highest to lowest abundance, a total of 775 Annelids, 15 Arthropods, 12 Echinoderms and 32 Molluscs were found. In terms of species abundance per area, annelids recorded the highest, followed by molluscs, arthropods, and echinoderms (Figure 2). Annelids were found in all stations, but more prevalent in Stations 1 to 3. Polychaete Caulleriella and Cirriformia (Figure 3) from Family Cirratulidae are found highest in terms of abundance overall. Both polychaete genera dominate soft-bottom sediments in stations 1 and 2. Cirratulid polychaetes are very ubiquitous in soft-bottom sediment globally (Idris $\&$ Arshad 2013). However, their abundance is highest in regions susceptible to ecological stresses such as industrial and sewage areas where pollutions such as oil spill and release of heavy metal constituent generally occurs (Ferrando \& Méndez, 2011). Both Caulleriella and Cirriformia polychaetes are found in other parts of waters surrounding Peninsular Malaysia such as in Merambong and Tanjung Adang Shoals (Guan et al., 2014) and Malaysian Exclusive Economic Zone in South China Sea (Rosli et al., 2018). Mediomastus (Family Capitellidae) and Prionospio (Family Spionidae) (Figure 3) polychaetes also account to higher abundance in station 1, and similar to Cirratulids polychaetes, they can be found in every soft-bottom sediment habitat and common in regions closer to shores and estuaries (Rehitha et al., 2017).

Molluscs were mostly found in Stations 1 to 3. Cerithidea snail (Figure 3) from Family Potamididae recorded the highest abundance in this phylum, and it was found in Station 1 and 2. Cerithidea snail is commonly found in soft-bottom sediment closer to estuaries and rocky shores and some species are found to attach themselves against human infrastructure such as dock and rock formations at beaches (Baharuddin et al., 2018 \& Halim et al., 2019). Cerithidea can be found in other parts of waters of Peninsular Malaysia such as Penang (Gholizadeh et al., 2012), Pulau Bidong (Baharuddin et al., 2018) and also previously recorded in mangrove habitat in Pulau Klang, Pulau Ketam and Pulau Mat Zin, neighbouring islands to Pulau Indah (Singh \& Baharin 2016). Arthropods were mostly found in Stations 
Table 1

Checklist of benthic macroinverterbate taxa found in all six stations in waters surrounding Pulau Indah, Klang

\begin{tabular}{|c|c|c|c|c|c|c|}
\hline & St1 & $\mathrm{St} 2$ & $\mathrm{St} 3$ & St4 & St5 & St6 \\
\hline \multicolumn{7}{|l|}{ Phylum Anelida } \\
\hline \multicolumn{7}{|l|}{ Class Polychaeta } \\
\hline \multicolumn{7}{|l|}{ Order Amphinomida } \\
\hline \multicolumn{7}{|c|}{ Family Amphinomidae } \\
\hline Eurythoe & & & & & 1 & \\
\hline \multicolumn{7}{|l|}{ Order Capitellida } \\
\hline \multicolumn{7}{|l|}{ Family Capitellidae } \\
\hline Capitella & 4 & & & & & \\
\hline Mediomastus & 82 & & 11 & & & \\
\hline Notomastus & & & 33 & & & \\
\hline Pulliela & & & 11 & & & \\
\hline Family Maldanidae & & & 2 & 1 & 2 & \\
\hline \multicolumn{7}{|l|}{ Order Cossurida } \\
\hline \multicolumn{7}{|l|}{ Family Cossuridae } \\
\hline Cossura & & & & & & 1 \\
\hline \multicolumn{7}{|l|}{ Order Eunicida } \\
\hline \multicolumn{7}{|l|}{ Family Eunicida } \\
\hline Eunice & & 2 & 3 & & & \\
\hline \multicolumn{7}{|l|}{ Order Flabelligerida } \\
\hline \multicolumn{7}{|c|}{ Family Flabelligeridae } \\
\hline Flabellina & 1 & & & & & \\
\hline \multicolumn{7}{|l|}{ Order Orbiniida } \\
\hline \multicolumn{7}{|l|}{ Family Orbiniidae } \\
\hline Scoloplella & & 3 & 1 & & & \\
\hline \multicolumn{7}{|l|}{ Order Phyllodocida } \\
\hline \multicolumn{7}{|c|}{ Suborder Aphroditiformia } \\
\hline \multicolumn{7}{|l|}{ Family Sigalionidae } \\
\hline Sthenelanella & & 2 & & & 5 & \\
\hline \multicolumn{7}{|c|}{ Suborder Glyceriformia } \\
\hline \multicolumn{7}{|l|}{ Family Glyceridae } \\
\hline Glycera & & & & 2 & 4 & 6 \\
\hline
\end{tabular}


Table 1 (Continued)

$\begin{array}{llllll}\text { St1 } & \text { St2 } & \text { St3 } & \text { St4 } & \text { St5 } & \text { St6 }\end{array}$

Family Goniadidae

Goniada

45

Suborder Nereidiformia

Family Hesionidae

Syllida

Family Pilargidae

Ancistrosyllis

Sigambra

7

$5 \quad 34$

Suborder Phyllodociformia

Family Phyllodocidae

Phyllodoce

Suborder Incertae Sedis

Family Nephtyidae

Micronepthys

9

Order Spionida

Suborder Spioniformia

Family Poecilochaetidae

Poecilochaetus

3

2

1

Family Spionidae

Prionospio

$\begin{array}{llll}157 & 3 & 3 & 10\end{array}$

4

Suborder Cirratuliformia

Family Cirratulidae

Caulleriella

$83 \quad 98$

4

Cirriformia

$130 \quad 43$

Order Terebellida

Family Terebellidae

Phylum Arthropoda

Order Amphipoda

Family Scinidae

Scina

Order Decapoda

Family Paraonoipediae

1 
Table 1 (Continued)

$\begin{array}{llllll}\text { St1 } & \text { St2 } & \text { St3 } & \text { St4 } & \text { St5 } & \text { St6 }\end{array}$

Family Xanthidae

Micropanope spinipes

Family Pontoporeiidae

Monoporeia

Order Euphausiacea

Family Euphasuiidae

Thysanoessa

Order Tanaidacea

Family Tanaidae

Tanais

Phylum Echinodermata

Order Holothuroidea

Family Cucumariidae

Thyonidium

Order Ophiuroidea

Family Amphiuridae

Ophiothrix

Family Ophiactidae

Ophiactis

$\begin{array}{lll}3 & 3 & 2\end{array}$

Phylum Mollusca

Order Caenogastropoda

Family Ceriithidae

Cerithium

Family Potamididae

Cerithidea rhizophorarum $\quad 5 \quad 5$

Cerithidea rhizophorarum morchii (var.) $\quad 8 \quad 2$

Order Littorinimorpha

Family Rissoidae

Alvania

Order Neogastropoda

Family Nassariidae 




Figure 2. Taxa abundance percentage for all phyla in each station per square area.

4 to 6. Two families of crabs were identified, namely Family Paraonoipediae and Xanthidae (Figure 3). These crabs were found in Stations 4 and 5 respectively. These families of crab are well-known to inhabit in estuary areas and occasionally found at submerged part of port and berth ( $\mathrm{Ng} \&$ Davie 2002). Both families are common families of crab in Strait of Malacca and major waterways in Indonesia ( $\mathrm{Ng}, 2017)$.

Zooplankton found in this study comprised amphipods, krills and tanaids (Figure 3). Like Brachyura crabs, majority of these individuals were found only in station 4 to 6 . Monoporeia and Scina amphipods, Thysanoessa krills and Tanais tanaids are generally found only in nutrient-rich water, which in this case their abundance in these stations may be attributed to the stations' closer proximity to multiple small estuaries with rich mangrove covers (Nakajima et al., 2019). Distribution of sea cucumber Thyodinium and brittle stars Ophiuthrix and Ophiactis is commonly restricted to only areas rich in nutrients (Kamarudin et al., 2015; Gondim et al., 2013). Sea cucumber Thyodinium is previously reported as common in Tanjung Piai, Johor (Ong \& Wong 2015), whereas Ophiuthrix and Ophiactis (Figure 3) are recorded in Strait of Johor (Fujita \& Irimura, 2015). Studies showed that these organisms prefer environment with higher nutrient affluent and organic materials, and that closer the habitat to estuaries, the higher the abundance of these Echinoderms (Ong \& Wong, 2015; Fujita \& Irimura, 2015). 


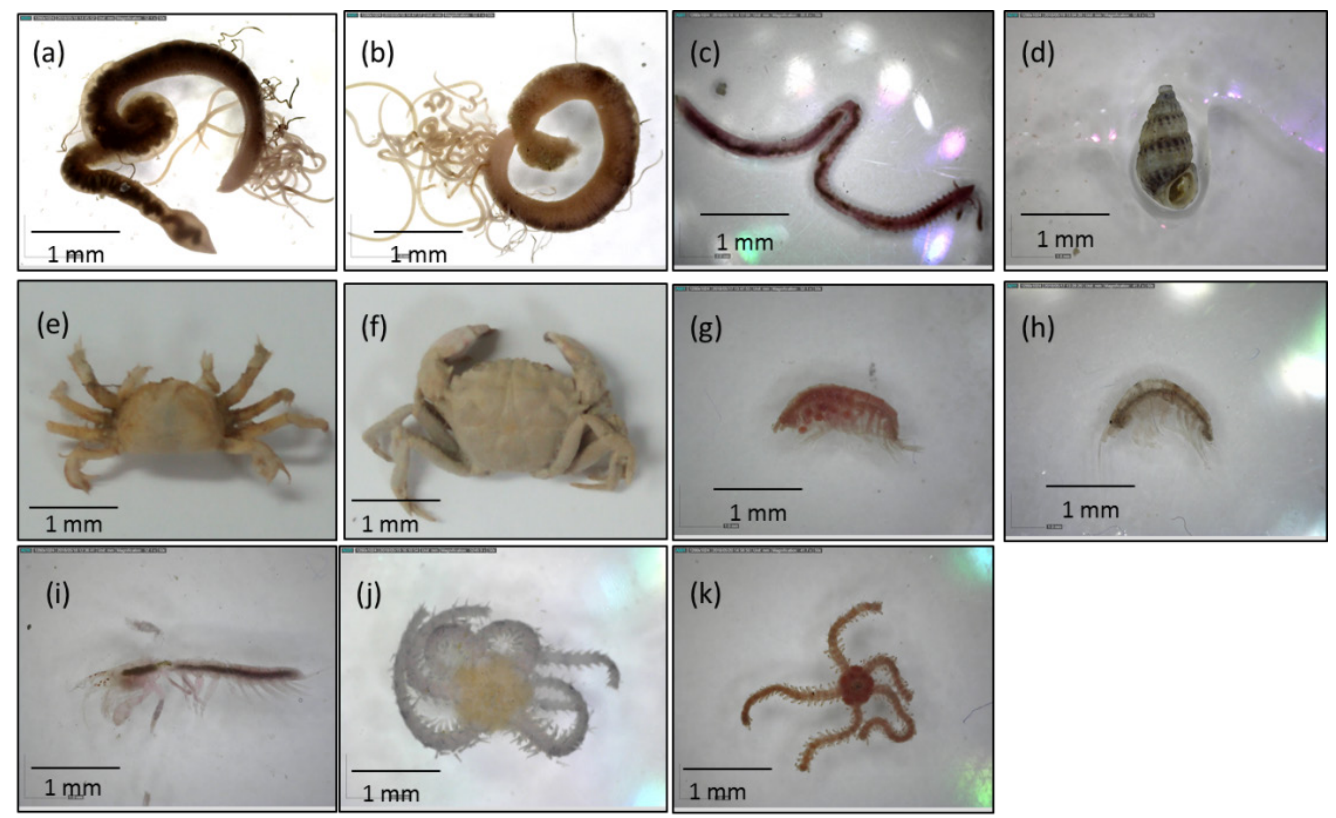

Figure 3. Assortment of representative genera found in this study. Annelids: (a) Cirriformia (b) Caulleriella (c) Prionospio; Gastropods: (d) Cerithidea; Arthropods: (e) Paraonoipediae crab (f) Micropanope (g) Monoporeia (h) Scina (i) Tanais; and Echinoderms: (j) Ophiothrix (k) Ophiactis

Taxonomic identification performed in this study was based on several studies such as Idris and Arshad (2013) for the annelids, Ong and Wong (2015) for the echinoderms, $\mathrm{Ng}$ (2017) for the arthropods and Baharuddin et al. (2018) for the molluscs. In addition, online websites such as WoRMS and MyBIS were also used as these online repositories are often updated by users all the time. Databases on online repositories may contain even more accurate location of targeted taxa as well as suitable naming nomenclature, biological traits, life cycle and even feeding behaviour (Horton et al., 2017).

\section{Assessment of Ecological and Environmental Parameters}

Table 2 shows ecological indices in terms of Shannon-Wiener Diversity Index $\left(H^{\prime}\right)$, Pielou's Evenness Index $\left(J^{\prime}\right)$ and Menhinick's Richness Index $\left(D_{m n}\right)$. For $H^{\prime}$ index, station 5 was the highest, followed by stations 6 and 3. Station 6 recorded the highest $J$ ' index value, while station 4 showed vice versa. Lastly, $D_{m n}$ recorded station 1 as the highest in all station followed by station 2 and 3 . Other stations, 4 to 6 , showed almost similar $D_{m n}$ index value. $H$ 'found in all stations especially in Station 5 was comparatively lower than the previous record of $H^{\prime}$ 'in Sany et al. (2014). Sany et al. (2014) focused on West Port, and Station 5 is located on it. Possible factor attributing to lower $H$ ' may be due to lower number of taxa found in this study compared to the number of taxa found in Sany et al. (2014). This study 
also did sampling session only once, whilst Sany et al. (2014) performed the sampling in the region several times, possibly explaining higher taxa number and specimen counts than this study.

Table 2

Population parameters and ecological indices for overall benthic macroinvertebrates in respective stations

\begin{tabular}{cccccc}
\hline Stations & Taxa No. & Density $\left(\right.$ ind.$\left./ \mathrm{m}^{2}\right)$ & $H^{\prime}$ & $J^{\prime}$ & $D_{m n}$ \\
\hline 1 & 11 & 21043.48 & 1.63 & 0.26 & 22.05 \\
2 & 11 & 7347.83 & 1.38 & 0.27 & 13.15 \\
3 & 13 & 5043.48 & 2.01 & 0.42 & 10.19 \\
4 & 8 & 1086.96 & 1.76 & 0.55 & 5.00 \\
5 & 10 & 1260.87 & 2.18 & 0.30 & 5.39 \\
6 & 9 & 1130.43 & 2.06 & 0.63 & 5.10 \\
\hline
\end{tabular}

As for environmental parameters, station 6 recorded the highest total organic carbon, followed by station 4 as the lowest record for the latter (Figure 5). As for sediment particle size assessment (Figure 4), stations 1 and 3 recorded highest percentage of coarse sand $(0.5 \mathrm{~mm})(52.24 \%, 49.16 \%)$. Stations 2,4 and 5, on the other hand, recorded highest particle size percentage fine sand $(67.13 \%, 84.61 \%$, and $75.45 \%)$. Lastly, station 6 showed highest percentage of granule $(2 \mathrm{~mm})(17.70 \%)$.

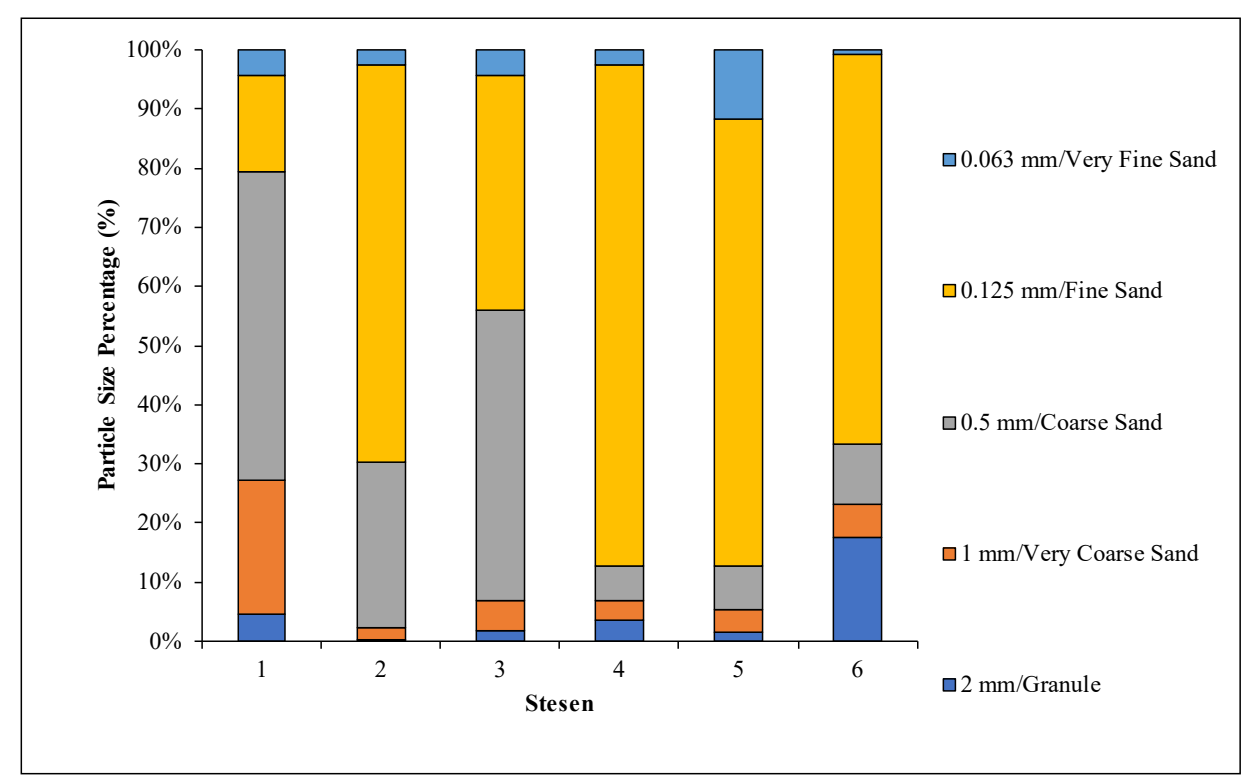

Figure 4. Percentages of sediment particle sizes in each respective station. 







\section{Correlation of Distribution and Diversity of Benthic Macroinvertebrate Community with Environmental Parameter}

Data Significance Between Stations. In terms of data significance, one-way ANOVA test showed no significant difference on both environmental parameters and benthic communities' abundance in all stations $(P>0.05)$.

Correlation Between Stations with Surrounding Environmental Parameters. Based on PCA analysis (Figure 6), stations 2, 4, and 5 were more attributed to fine sand ( 0.125 $\mathrm{mm}$ particle size sediment). These stations are located in between islands or mainland. Fine sand is common in this area. Bolam et al. (2016) reported aggregation of snails, polychaetes such as Spionids and Cirratulids and brittle star such as Ophiuroids in seafloor nearby a dredge disposal area, northeast coast of England, where active sedimentation process took place. Similarly, the coastline is also passed frequently by ships from other part of England. Benthic taxa found in Bolam et al. (2016) were smaller in size and their availability in sediments might be attributed to their ability to transverse across smallersized sediment to catch food and survivability from larger-sized predators such as crabs and Errantia polychaetes.

PCA analysis also showed that Station 1 and 3 were more attributed to coarse sand ( $0.5 \mathrm{~mm}$ sediment size). Station 1 is located nearby estuaries of Sungai Klang which is connected directly into Selangor inland, whilst station 3 is located nearby Sungai Langat. Sedimentation from these rivers were lower, hence might explain higher percentage of medium-sized sand but lesser extremities. Harris \& Aris (2015) studied bioaccumulation of metals on these two rivers and reported lower sedimentation rate from both rivers inland. Polychaetes and gastropods were found in larger abundance in these two stations, with Sedentaria polychaetes (Capitellids, Cirratulids, Spionids) dominating the sediment by whole. Hill et al. (2013) conducted survey on dominance of these three polychaete family in Sydney Harbour, Australia, and associated large presence of these polychaete groups with presence of substrata in sediment such as PAH and heavy metals.

Lastly, PCA analysis indicated that station 6 was more attributed towards very fine sand (0.063 mm sediment size), very course sand (1 mm sediment size) and granules (2 $\mathrm{mm}$ sediment size), water depth, salinity and TOC. Station 6 is located closer to estuaries from Pulau Kelang, an island with mangrove biotope. Previous study by Sany et al. (2014) at shipping route nearby this study's station 6 recorded variation of Errantia polychaetes, gastropods and molluscs, and these variations were attributed to high concentration of organic nutrients such as phosphate and nitrate originating from estuaries of Pulau Kelang which might fuel phytoplankton leading to establishment of food web in the region by other organisms. Similarly, study by Barros et al. (2012) on mangrove estuaries in Brazil recorded highly diverse polychaete community, in which their occurrence were attributed to higher flux of organic carbon in sediment, originating from sediments drifting away from 
Mohd Sophian Mohd Kasihmuddin and Zaidi Che Cob

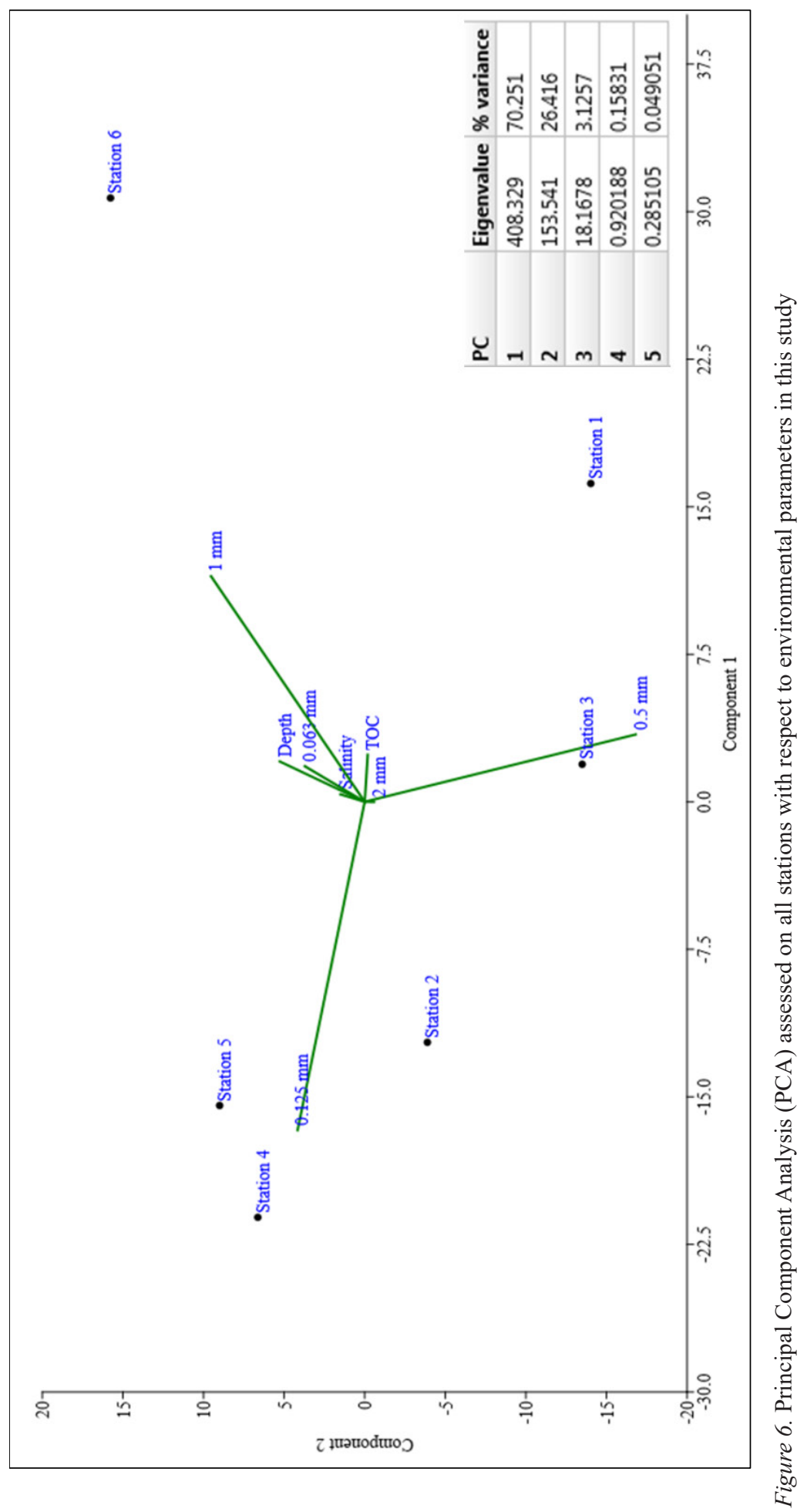


mangrove roots. Their study also considered salinity as the driving factor for diversity of benthic community in the region. It may be possible that sedimentation process from Pulau Kelang mangrove estuaries might end up transporting more sediment offshore, in which sediment might contain enough organic materials for taxa in the region.

Correlation Between Benthic Taxa with Environmental Parameters. Pearson correlation analysis (refer to attached Excel file) indicated several genera of benthic macroinvertebrates had positive and negative correlations towards certain environmental parameters recorded in this study. For polychaete groups, Cossura had positive correlation with salinity, very fine sand $(0.063 \mathrm{~mm})$ and very coarse sand $(1 \mathrm{~mm})$; Glycera positively correlated to very fine sand $(0.063 \mathrm{~mm})$; Micronepthys positively correlated to $2 \mathrm{~mm}$ and Poecilochaetus positively correlated to course sand $(0.5 \mathrm{~mm})$. Cossura polychaete is commonly found in muddy sediment, and previously recorded in Bay of Bengal (Smitha et al., 2017) and in dredge disposal zone in Brazilian estuary (Sousa et al. 2019). Glycera bloodworm is common in smaller grain-sized sediment where it is easier to transverse to catch prey, and previously recorded in sediments of Sepetiba Bay, Brazil, with higher percentage on smaller-sized grain such as mud and silt (Mattos et al., 2013). Micronepthys is commonly found in sub-tidal areas where larger-sized sediment dominate the region (Murray et al., 2017), and previous report by Shakouri et al. (2017) showed records of the genus abundance in sub-tidal areas of Chabahar Bay, Iran. Peocilochaetus is common in sandy sediment closer to estuaries. Previous record by Raut et al. (2013) on east coast of India reported the finding of this genus in sediment closer to recently cleaned-up Boat Harbour.

In terms of Arthropod groups, both Monoporeia and Thysanoessa have positive correlation to salinity, very fine sand $(0.063 \mathrm{~mm})$ and very coarse sand $(1 \mathrm{~mm})$. Tanais was positively correlated to very coarse sand $(1 \mathrm{~mm})$. Previous records of these arthropods showed higher abundance of Monoporeia amphipod, Thysanoessa krill and Tanais tanaid in estuary and intertidal zones where salinity gradient was present along the zone, and higher percentage of smaller-sized grain sediment such as mud and silt present in the area (Wiklund \& Andersson, 2014; Cabrol et al., 2019; Pandiyarajan et al., 2020).

For echinoderms, Ophiactis' abundance was negatively correlated to coarse sand $(0.5$ $\mathrm{mm}$ ). Previous record on Ophiactis in Johor Straits showed higher abundance of the genus in mud and silts rather than in larger-sized sediment (Fujita \& Irimura, 2015). Oppositely, mollusc Cerithidea rizopharum showed positive correlation to coarse sand $(0.5 \mathrm{~mm})$. Cerithidea is a common gastropod readily found in intertidal areas closer to port and berth where sands are in highest percentage of grain-size percentage (Reid \& Claremont, 2014). 


\section{CONCLUSION}

This study concludes that annelids were highest in terms distribution and diversity in all study areas, whilst distribution and diversity of other phyla were limited to certain study areas only. Ecological indices showed highest diversity index in Station 5, highest evenness in Station 6 and highest richness index in Station 1. Correlation study showed sediment particle size as a major factor that differentiated all stations in study, and also a major factor that correlated positively on eight benthic taxa in this study and another one taxon attained negative correlation on the same factor.

As benthic studies in Malaysia as a whole are still very inadequate, especially in areas with heavy human interference, this study can serve as a good starting point for more extensive studies regarding ecological stresses in benthic communities in other main ports in Sabah, Sarawak and Johor. Through this study, we can create a good comparison and generalization on conditions in benthic communities in these regions, and if possible, recommend actions to reduce any loss taxa of benthic community ecological stresses induced by pollutants such as heavy metal, oil spills and improper handling of domestic wastes.

\section{ACKNOWLEDGEMENT}

We sincerely thank Mr. Zuhaimi from the Marine Science Program, Universiti Kebangsaan Malaysia for his dedicated efforts on sample collection. This work was funded by Fundamental Research Grant, Ministry of Higher Education, Malaysia (Project No. FRGS/1/2017/STG03/UKM/02/5).

\section{REFERENCES}

Al-Khayat, J. A., Abdulla, M. A., \& Alatalo, J. M. (2018). Diversity of benthic macrofauna and physical parameters of sediments in natural mangroves and in afforested mangroves three decades after compensatory planting. Aquatic Sciences, 81(1), 1-18. doi: https://doi.org/10.1007/s00027-018-0599-7

Altuhafi, F., \& Baudet, B. A. (2011). A hypothesis on the relative roles of crushing and abrasion in the mechanical genesis of a glacial sediment. Engineering Geology, 120(1-4), 1-9. doi: https://doi.org/10.1016/j. enggeo.2011.03.002

Arbi, I., Zhang, J., Liu, S., Wu, Y., \& Huang, X. (2017). Benthic habitat health assessment using macrofauna communities of a sub-tropical semi-enclosed bay under excess nutrients. Marine Pollution Bulletin, 119(2), 39-49. doi: https://doi.org/10.1016/j.marpolbul.2017.03.042

Baharuddin, N., Basri, N. B., \& Syawal, N. H. (2018). Marine gastropods (Gastropoda; mollusca) diversity and distribution on intertidal rocky shores of Terengganu, Peninsular Malaysia. AACL Bioflux, 11(4), 1144-1154. 
Barros, F., de Carvalho, G. C., Costa, Y., \& Hatje, V. (2012). Subtidal benthic macroinfaunal assemblages in tropical estuaries: Generality amongst highly variable gradients. Marine Environmental Research, 81, 43-52. doi: https://doi.org/10.1016/j.marenvres.2012.08.006

Belal, A. A. M., Kelany, M. S., Hamed, M. M., \& El-Fattah, L. S. A. (2020). Selected bacterial communities associated with macro-benthic fauna assemblages at the Timsah Lake and the Western Lagoon's sediments, Suez Canal, Egypt. Egyptian Journal of Aquatic Research, 46(2), 137-143. doi: https://doi.org/10.1016/j. ejar.2020.02.003

Bernardino, A. F., de Oliveira Gomes, L. E., Hadlich, H. L., Andrades, R., \& Correa, L. B. (2018). Mangrove clearing impacts on macrofaunal assemblages and benthic food webs in a tropical estuary. Marine Pollution Bulletin, 126, 228-235. doi: https://doi.org/10.1016/j.marpolbul.2017.11.008

Bernhard, J. M., Ostermann, D. R., Williams, D. S., \& Blanks, J. K. (2006). Comparison of two methods to identify live benthic foraminifera: A test between Rose Bengal and CellTracker Green with implications for stable isotope paleoreconstructions. Paleoceanography, 21(4), 1-8. doi: https:/doi. org/10.1029/2006PA001290

Bolam, S. G., McIlwaine, P. S. O., \& Garcia, C. (2016). Application of biological traits to further our understanding of the impacts of dredged material disposal on benthic assemblages. Marine Pollution Bulletin, 105(1), 180-192. doi: https://doi.org/10.1016/j.marpolbul.2016.02.031

Cabrol, J., Trombetta, T., Amaudrut, S., Aulanier, F., Sage, R., Tremblay, R., ... \& Winkler, G. (2019). Trophic niche partitioning of dominant North-Atlantic krill species, Meganyctiphanes norvegica, Thysanoessa inermis, and T. raschii. Limnology and Oceanography, 64(1), 165-181. doi: https://doi.org/10.1002/ $\operatorname{lno} .11027$

ELTurk, M., Abdullah, R., Zakaria, R. M., \& Bakar, N. K. A. (2019). Heavy metal contamination in mangrove sediments in Klang estuary, Malaysia: Implication of risk assessment. Estuarine, Coastal and Shelf Science, 226, 1-7. doi: https://doi.org/10.1016/j.ecss.2019.106266

Fauchald, K., Jumars, P.A. (1979). The diet of worms: A study of polychaete feeding guilds. Oceanography Marine Biology Annual Review, 17, 193-284.

Ferrando, A., \& Méndez, N. (2011). Efectos de la contaminación orgánica sobre la distribución de las comunidades de anélidos en la laguna costera "estero de urías" (Mexico) [Effects of organic pollution on the distribution of annelid communities in the coastal lagoon, Urias estuary (Mexico)]. Scientia Marina, 75(2), 351-358. doi: https://doi.org/10.3989/scimar.2011.75n2351

Fujita, T., \& Irimura, S. (2015). Preliminary list of ophiuroids (Echinodermata: Ophiuroidea) collected from the Johor Straits, Singapore. Raffles Bulletin of Zoology, 2015(31), 264-272.

Gholizadeh, M., Yahya, K., Talib, A., \& Ahmad, O. (2012). Effects of environmental factors on polychaete assemblage in Penang National Park, Malaysia. World Academy of Science, 72(December 2012), 669-672. 
Gondim, A. I., Alonso, C., Dias, T. L. P., Manso, C. L. C., \& Christoffersen, M. L. (2013). A taxonomic guide to the brittle-stars (Echinodermata, Ophiuroidea) from the State of Paraíba continental shelf, Northeastern Brazil. ZooKeys, 307, 45-96. doi: https://doi.org/10.3897/zookeys.307.4673

Guan, W. S., Ghaffar, M. A., Ali, M. M., \& Cob, Z. C. (2014). The Polychaeta (Annelida) communities of the Merambong and Tanjung Adang Shoals, Malaysia, and its relationship with the environmental variables. Malayan Nature Journal, 66(1-2), 168-183.

Halim, S. S. A., Shuib, S., Talib, A. \& Yahya, K. (2019). Species composition, richness, and distribution of molluscs from intertidal areas at Penang Island, Malaysia. Songklanakarin Journal of Science and Technology, 41(1), 165-173.

Hanapiah, M., Zulkifli, S. Z., Mustafa, M., Mohamat-Yusuff, F., \& Ismail, A. (2018). Isolation, characterization, and identification of potential Diuron-degrading bacteria from surface sediments of Port Klang, Malaysia. Marine Pollution Bulletin, 127, 453-457. doi: https://doi.org/10.1016/j.marpolbul.2017.12.015

Harris, H. \& Aris, A. Z. (2015). Distribution of metals and quality of intertidal surface sediment near commercial port and estuaries of urbanized rivers in Port Klang, Malaysia. Environmental Earth Sciences, 73, 72057218. doi: 10.1007/s12665-014-3900-7

Hill, N. A., Simpson, S. L., \& Johnston, E. L. (2013). Beyond the bed: Effects of metal contamination on recruitment to bedded sediments and overlying substrata. Environmental Pollution, 173, 182-191. doi: https://doi.org/10.1016/j.envpol.2012.09.029

Horton, T., Gofas, S., Kroh, A., Poore, G. C. B., Read, G., Rosenberg, G., ... \& Vranken, S. E. (2017). Improving nomenclatural consistency: A decade of experience in the World Register of Marine Species. European Journal of Taxonomy, 2017(389), 1-24. doi: https://doi.org/10.5852/ejt.2017.389

Hossain, M. B. (2018). Trophic functioning of macrobenthic fauna in a tropical acidified Bornean estuary (Southeast Asia). International Journal of Sediment Research, 34(1), 48-57. doi: https://doi.org/10.1016/j. ijsrc.2018.08.002

Huntington, T. G., Ryan, D. F., \& Hamburg, S. P. (1988). Estimating soil nitrogen and carbon pools in a northern hardwood forest ecosystem. Soil Science Society of America Journal, 52(4), 1162-1167. doi: https://doi. org/10.2136/sssaj1988.03615995005200040049x

Idris, I., \& Arshad, A. (2013). Checklist of polychaetous annelids in Malaysia with redescription of two commercially exploited species. Asian Journal of Animal and Veterinary Advances, 8(3), 409-436. doi: 10.3923/ajava.2013.409.436

Kamarudin, K. R., Usup, G., Hashim, R., \& Rehan, M. M. (2015). Sea cucumber (Echinodermata: Holothuroidea) species richness at selected localities in Malaysia. Pertanika Tropical Agricultural Science, 38(1), 7-32.

Lu, L. (2005). Seasonal variation of macrobenthic infauna in the Johor Strait, Singapore. Aquatic Ecology, 39(1), 107-111. doi: https://doi.org/10.1007/s10452-004-7111-2 
Mason, N. W. H., Mouillot, D., Lee, W. G., \& Wilson, J. B. (2005). Functional richness, functional evenness and functional divergence: The primary components of functional diversity. Oikos, 111(1), 112-118. doi: https://doi.org/10.1111/j.0030-1299.2005.13886.x

Mattos, G., Cardoso, R. S., \& Santos, A. S. D. (2013). Environmental effects on the structure of polychaete feeding guilds on the beaches of Sepetiba Bay, south-eastern Brazil. Journal of the Marine Biological Association of the United Kingdom, 93(4), 973-980. doi: https://doi.org/10.1017/S0025315412000707

Mohamamad, A., \& Jalal, K. C. A. (2018). Macrobenthic diversity and community composition in the Pahang Estuary, Malaysia. Journal of Coastal Research, 82(4), 206-211. doi: https://doi.org/10.2112/SI82-030.1

Mosbahi, N., Serbaji, M. M., Pezy, J. P., Neifar, L., \& Dauvin, J. C. (2019). Response of benthic macrofauna to multiple anthropogenic pressures in the shallow coastal zone south of Sfax (Tunisia, central Mediterranean Sea). Environmental Pollution, 253, 474-487. doi: https://doi.org/10.1016/j.envpol.2019.06.080

Murray, F., Solan, M., \& Douglas, A. (2017). Effects of algal enrichment and salinity on sediment particle reworking activity and associated nutrient generation mediated by the intertidal polychaete Hediste diversicolor. Journal of Experimental Marine Biology and Ecology, 495, 75-82. doi: 10.1016/j. jembe.2017.06.002

Nakajima, R., Yoshida, T., Othman, B. H. R., \& Toda, T. (2009). Diel variation of zooplankton in the tropical coral-reef water of Tioman Island, Malaysia. Aquatic Ecology, 43(4), 965-975. doi: https://doi.org/10.1007/ s10452-008-9208-5

Ng, P. K. L. (2017). On the identities of the highland vampire crabs, Geosesarma foxi (Kemp, 1918) and G. serenei Ng, 1986, with description of a new phytotelmic species from Penang, Peninsular Malaysia (Crustacea: Decapoda: Brachyura: Sesarmidae). Raffles Bulletin of Zoology, 65, 226-242.

Ng, P. K. L., \& Davie, P. J. F. (2002). A checklist of the brachyuran crabs of Phuket and Western Thailand. Phuket Marine Biological Center Special Publication, 23(2), 369-384.

Omar, T. F. T., Aris, A. Z., Yusoff, F. M., \& Mustafa, S. (2018). Occurrence, distribution, and sources of emerging organic contaminants in tropical coastal sediments of anthropogenically impacted Klang River estuary, Malaysia. Marine Pollution Bulletin, 131, 284-293. doi: https://doi.org/10.1016/j.marpolbul.2018.04.019

Ong, J. Y., \& Wong, H. P. S. (2015). Sea cucumbers (Echinodermata: Holothuroidea) from the Johor Straits, Singapore. Raffles Bulletin of Zoology, 2015(31), 273-291.

Pandiyarajan, R. S., Jyothibabu, R., Jagadeesan, L., \& Arunpandi, N. (2020). Ecology and distribution of tanaids in a large tropical estuary along the Southwest Coast of India. Regional Studies in Marine Science, 33(2020), 1-12. doi: https://doi.org/10.1016/j.rsma.2019.101032

Queirós, A. M., Birchenough, S. N. R., Bremner, J., Godbold, J. A., Parker, R. E., Romero-Ramirez, A., ... \& Widdicombe, S. (2013). A bioturbation classification of European marine infaunal invertebrates. Ecology and Evolution, 3(11), 3958-3985. doi: https://doi.org/10.1002/ece3.769

Quimpo, T. J. R., Ligson, C. A., Manogan, D. P., Requilme, J. N. C., Albelda, R. L., Conaco, C., \& Cabaitan, P. C. (2020). Fish farm effluents alter reef benthic assemblages and reduce coral settlement. Marine Pollution Bulletin, 153, 1-7. doi: https://doi.org/10.1016/j.marpolbul.2020.111025 
Raut, D., Raman, P. E., Raman, A. V., \& Patnaik, L. (2013). Assessment of Benthic community alterations in relation to pollution in a boat harbor in Visakhapatnam, East Coast of India. The Ecoscan, 7(1\&2), 51-56.

Rehitha, T. V., Ullas, N., Vineetha, G., Benny, P. Y., Madhu, N. V., \& Revichandran, C. (2017). Impact of maintenance dredging on microbenthic community structure of a tropical estuary. Ocean and Coastal Management, 144(2017), 71-82.

Reid, D. G., \& Claremont, M. (2014). The genus Cerithideopsis Thiele, 1929 (Gastropoda: Potamididae) in the Indo-West Pacific region. Zootaxa, 3779(1), 61-80. doi: https://doi.org/10.11646/zootaxa.3779.1.8

Rosli, N. S., Yahya, N., Idris, I., \& Bachok, Z. (2018). Polychaetous annelid community structure in relation to soft bottom sediment characteristics in continental shelf of the southern South China Sea. Journal of Sustainability Science and Management, 13(5), 125-146.

Shakouri, A., Mortimer, K., \& Dehani, E. (2017). A new species and new records of Magelona (Annelida: Magelonidae) from Chabahar Bay, Gulf of Oman, South-eastern Iran. Journal of the Marine Biological Association of the United Kingdom, 97(7), 1537-1552. doi: https://doi.org/10.1017/S002531541600076X

Singh, H. R., \& Baharin, N. K. (2016). Gastropod community structure from varying levels of mangrove disturbance in Selangor, Malaysia. Malaysian Forester, 79(1-2), 54-63.

Smitha, C. K., Raveendran, T. V., Rosamma, P., \& Damodaran, R. (2017). First Record of the polychaete Cossura aciculata from Indian Waters. Journal on New Biological Reports, 6(2), 82-85.

Sousa, L. K. S., Júnior, M. N., Cutrim, M. V. J., \& de Oliveira, V. M. (2019). Cossura yacy sp. nov. (cossuridae, annelida) from a tropical brazilian estuary. Iheringia - Serie Zoologia, 109, 1-9.

Sany, S. B. T., Hashim, R., Salleh, A., Rezayi, M., \& Safari, O. (2015). Ecological quality assessment based on macrobenthic assemblages indices along West Port, Malaysia coast. Environmental Earth Sciences, 74(2), 1331-1341. doi: 10.1007/s12665-015-4122-3

Sany, S. B. T., Rezayi, M., Hashim, R., Salleh, A., \& Safari, O. (2014). Diversity and distribution of benthic invertebrates. International Journal of Environmental, Ecological, Geological and Mining Engineering, $8(7), 458-461$.

Taupp, T., \& Wetzel, M. A. (2018). Functionally similar but taxonomically different: Benthic communities in 1889 and 2006 in an industrialized estuary. Estuarine, Coastal and Shelf Science, 217, 292-300. doi: https://doi.org/10.1016/j.ecss.2018.11.012

Vijapure, T., Sukumaran, S., Neetu, S., \& Chandel, K. (2018). Macrobenthos at marine hotspots along the northwest Indian inner shelf: Patterns and drivers. Marine Environmental Research, 144(December 2018), 111-124. doi: https://doi.org/10.1016/j.marenvres.2018.12.007

Wiklund, A. K. E., \& Andersson, A. (2014). Benthic competition and population dynamics of Monoporeia affinis and Marenzelleria sp. in the northern Baltic Sea. Estuarine, Coastal and Shelf Science, 144, 46-53. doi: https://doi.org/10.1016/j.ecss.2014.04.008

Zhen, W. L., Teoh, H. W., Lee, C. W., Lee, S. L., Saito, H., \& Chong, V. C. (2020). Macrobenthic community associated with semi-cultured blood cockles (Tegillarca granosa) in tropical mudflats. Continental Shelf Research, 195, 1-11. doi: https://doi.org/10.1016/j.csr.2020.104061 